\title{
KONTRIBUSI KOMPETENSI MEMBACA GAMBAR TEKNIK TERHADAP KOMPETENSI TEKNIK PEMESINAN BUBUT SISWA SMK
}

\author{
Ahmad M. Fahrudin ${ }^{1}$, Haryadi $^{2}$, Sabri $^{3}$ \\ Departemen Pendidikan Teknik Mesin \\ Universitas Pendidikan Indonesia \\ Jl. Dr. Setiabudhi No. 207 Bandung 40154 \\ ahmadmalikfahrudin@gmail.com
}

\begin{abstract}
ABSTRAK
Penelitian ini bertujuan untuk memperoleh gambaran tentang penguasaan peserta didik terhadap kompetensi membaca gambar teknik dan kompetensi teknik pemesinan bubut juga untuk memperoleh data tentang kontribusi kompetensi membaca gambar teknik terhadap kompetensi teknik pemesinan bubut pada peserta didik. Metode yang digunakan adalah metode deskriftif korasional ini dengan variabel bebas Kompetensi Membaca Gambar Teknik dan variabel terikat Kompetensi Teknik Pemesinan Bubut. Perolehan data dilakukan dengan mengadakan tes dan dokumentasi pada peserta didik kelas XI TPM SMK Negeri 6 Bandung Tahun ajaran 2014/2015 dengan jumlah populasi 138 orang dari 4 kelas. Penentuan sampel dalam penelitian ini dengan menggunakan rumus yang dikembangkan oleh Issac dan Michael dengan tingkat kesalahan 5\%, sehingga sampel dalam penelitian ini adalah peserta didik dengan jumlah 91 orang. Hasil dalam penelitian ini adalah (1) Berdasarkan hasil penelitian menunjukan bahwa 79 peserta didik memiliki penguasaan membaca gambar teknik yang masuk kedalam kategori sudah memenuhi standar kkm. (2) Berdasarkan hasil penelitian menunjukan bahwa 81 peserta didik memiliki penguasaan kompetensi dalam kerja bubut sederhana yang termasuk kedalam kategori sudah memenuhi standar kkm. (3) Kompetensi Membaca Gambar Teknik berkontribusi sedang terhadap Kompetensi Teknik Pemesinan Bubut.
\end{abstract}

Kata Kunci: Kontribusi, Gambar Teknik, Pemesinan, Bubut.

\section{PENDAHULUAN}

Sekolah Menengah Kejuruan (SMK) merupakan suatu lembaga pendidikan formal yang lulusannya dipersiapkan untuk memasuki dunia kerja. Mereka di tuntut agar menjadi manusia yang produktif, mampu bekerja mandiri, mampu memilih karier, ulet, gigih dalam berkopetensi, dan bertanggung jawab dalam menjalankan tugas dan kewajibannya. Upaya untuk mempersiapkan peserta didik yang lulusannya diorientasikan pada dunia kerja, maka penyelenggara proses pendidikannya harus relevan dan mengarah pada tujuannya.

Berdasarkan hasil penelitian pendahuluan, hasil belajar gambar teknik peserta didik yang merupakan gambaran tingkat penguasaan dalam kompetensi gambar teknik belum sesuai yang diharapkan. Jumlah peserta didik (SMKN 6 Bandung) yang mendapatkan nilai dengan kualifikasi baik sejumlah 27 orang setara 19,57\%, yang mendapat nilai dengan kualifikasi

\footnotetext{
${ }^{1}$ Mahasiswa Departemen Pendidikan Teknik Mesin FPTK UPI

${ }^{2}$ Dosen Departemen Pendidikan Teknik Mesin FPTK UPI

${ }^{3}$ Dosen Luar Biasa Departemen Pendidikan Teknik Mesin FPTK UPI
} 
cukup sejumlah 95 orang setara dengan 68,84\%, dan yang mendapat nilai kualifikasi kurang sejumlah 16 orang setara dengan 11,59\%. Berdasarkan data tersebut, ternyata masih ada 16 orang peserta didik yang belum memenuhi Kriteria Ketuntasan Maksimal (KKM) sebesar 76. Keadaan tersebut menggambarkan bahwa peserta didik mengalami suatu masalah untuk mencapai standar kompetensi berikutnya, karena peserta didik harus memperbaiki atau mengulang dulu kompetensi yang dianggap belum lulus hingga mencapai batas nilai KKM.

Adapun data dari hasil belajar praktikum pemesinan yang merupakan gambaran tingkat penguasaan dalam kompetensi teknik permesinan (Surakhmad, 2000). Jumlah peserta didik yang mendapatkan nilai dengan kualifikasi baik sekali sejumlah 10 setara 7,25\%, baik sejumlah 46 orang setara 33,33\%, yang mendapat nilai dengan kualifikasi cukup sejumlah 77 orang setara dengan 55,80\%, dan yang mendapat nilai kualifikasi kurang sejumlah 5 orang setara dengan 3,62\%. Berdasarkan data tersebut, ternyata masih ada 5 orang peserta didik yang belum memenuhi (KKM) sebesar 76.

Hal ini dapat dipahami, bahwa pada mata pelajaran teknik pemesinan tanpa menguasai gambar teknik, peserta didik akan kesulitan dalam melakukan praktikum pemesinan. Oleh karena itu dalam praktek pemesinan, peserta didik diberi gambar kerja, yang hanya dapat dipahami oleh mereka yang telah menguasai gambar teknik. Selain itu, bagi operator didalam dunia industri pun harus mampu mengartikan seluruh informasi yang ada didalam gambar kerja seperti toleransi, tingkat kekasaran permukaan, simbol-simbol dalam gambar kerja, penunjukan ukuran, gambar potongan, serta gambar susunan. Oleh karena itu, penguasaan gambar teknik tidak dapat dipisahkan dari kemampuan melakukan praktikum pemesinan. Dengan kata lain, mata pelajaran gambar teknik sangat menunjang terhadap mata pelajaran teknik permesinan (Suherman dan Hidayat, 2008).

Agar dicapai hasil yang optimal dari suatu penelitian, maka terlebih dahulu dirumuskan tujuan yang terarah. Tujuan penelitian ini, yaitu: untuk memperoleh gambaran tentang penguasaan kompetensi membaca gambar teknik pada peserta didik; memperoleh gambaran tentang penguasaan kompetensi teknik pemesinan bubut pada peserta didik; dan memperoleh gambaran kontribusi kompetensi membaca gambar teknik terhadap kompetensi teknik pemesinan bubut pada peserta didik . 
Kompetensi merupakan pengetahuan, keterampilan, nilai dan sikap dasar yang direfleksikan dalam kebiasaan berfikir dan bertindak yang bersifat dinamis, berkembang, dan dapat diraih setiap waktu. Kompetensi merupakan penguasaan terhadap suatu tugas, keterampilan, sikap, dan apresiasi yang diperlukan untuk menunjang keberhasilan (Mulyasa, 2003).

Kopetensi gambar teknik merupakan kopetensi kejuruan yang ada pada program keahlian teknik pemesinan. Kopetensi gambar teknik ini memiliki Standar Kopetensi (SK) dan Kopetensi Dasar (KD). Salah satu SK dalam kopetensi ini adalah membaca gambar teknik dengan Kompetensi Dasarnya adalah mendeskripsikan gambar teknik, memilih teknik gambar yang benar, dan membaca gambar teknik. Kompetensi ini sangat menunjang terhadap kopetensi lain, adapun kemampuan yang dipelajari dalam kompetensi membaca Gambar Teknik adalah gambar pandangan, gambar potongan, penunjukan ukuran, toleransi ukuran, tanda pengerjaan, dan simbol yang digunakan (SMKN 6, 2009).

\section{METODE PENELITIAN}

Metode yang digunakan adalah metode penelitian deskriptif korelasional. Penelitian ini tertuju pada pemecahan masalah yang ada pada masa sekarang, dan dengan tujuan utama untuk membuat penggambaran tentang sesuatu keadaan secara objektif dalam suatu deskripsi situasi. Metode deskriptif korelasional ini menggambarkan tentang hubungan antara dua variabel atau lebih dengan mendeskripsikan data, sehingg diketahui kontribusi kompetensi membaca gambar teknik terhadap kompetensi teknik pemesinan bubut. Penelitian ini dilakukan pada peserta didik kelas XI pada tahun ajaran 2014/2015 SMK Negeri 6 Bandung program keahlian teknik pemesinan dengan jumlah peserta didik yang menjadi sampel sebanyak 91 orang sebagai subjek penelitian dari jumlah populasi 126 orang.

\section{HASIL PENELITIAN}

Hasil penelitian menunjukkan bahwa kompetensi membaca gambar teknik, ada 4 orang tergolong kategori tinggi, 79 orang tergolong sudah memenuhi kriteria standar KKM, dan 8 orang tergolong kriteria rendah (Tabel 1). Kompetensi teknik pemesinan bubut, ada 2 orang tergolong kategori tinggi, 81 orang tergolong sudah memenuhi kriteria standar KKM, dan 8 orang tergolong kriteria rendah (Tabel 2). 
Tabel 1. Hasil Nilai Membaca Gambar Teknik

\begin{tabular}{|c|c|c|c|}
\hline \multicolumn{4}{|c|}{ Data Nilai Membaca Gambar Teknik } \\
\hline \multirow{2}{*}{ Data } & \multicolumn{2}{|c|}{ Nilai } & \multirow{2}{*}{ Skor total } \\
\hline & Kognitif & Psikomotor & \\
\hline $\operatorname{Max}$ & 83,89 & 94 & 87,94 \\
\hline Min & 49,78 & 63 & 62,65 \\
\hline Rata-rata & 68,88 & 80,44 & 76,59 \\
\hline $\mathrm{S}$ & 5 & & \\
\hline
\end{tabular}

Tabel 2. Hasil Nilai Teknik Pemesinan Bubut

\begin{tabular}{lccc}
\hline \multicolumn{4}{c}{ Data Nilai Pemesinan Bubut } \\
\hline \multirow{2}{*}{ Data } & \multicolumn{2}{c}{ Nilai } & Skor total \\
\cline { 2 - 3 } & Kognitif & Psikomotor & \\
\hline Max & 88,85 & 98,75 & 93,06 \\
Min & 68,96 & 78,45 & 78,35 \\
Rata-rata & 77,37 & 92,40 & 87,39 \\
\multicolumn{1}{c}{ S } & 3 & & \\
\hline
\end{tabular}

Analisis korelasi ini dilakukan untuk mengetahui bagaimana hubungan antara variabel kompetensi membaca gambar teknik dengan variabel kompetensi teknik pemesinan bubut). Penelitian ini menggunakan statistik regresi sederhana dengan dibantu menggunakan tabel anareg. Hasil perhitungan koefisien korelasi dengan menggunakan regresi sederhana diperoleh harga hitung $\mathrm{r}=0,4528$. Berdasarkan penafsiran kriteria korelasi, diartikan tergolong kategori sedang (Tabel 3).

Besarnya pengaruh antara variabel penelitian dapat dicari dengan menghitung koefisien determinasi. Besarnya pengaruh variabel $\mathrm{X}$ terhadap variabel $\mathrm{Y}$ dicari dengan menggunakan rumus koefisien determinasi (KD). Hasil perhitungan diperoleh harga $\mathrm{KD}=$ 20,50\%. Artinya variabel kompetensi membaca gambar teknik mempengaruhi variabel kompetensi teknik pemesinan bubut sebesar 20,50\%, sedangkan sisanya 79,50\% terdapat faktor lain yang mempengaruhi terhadap kompetensi Teknik Pemesinan (Tabel 3). 
Tabel 3. Hasil Analisis Data Penelitian

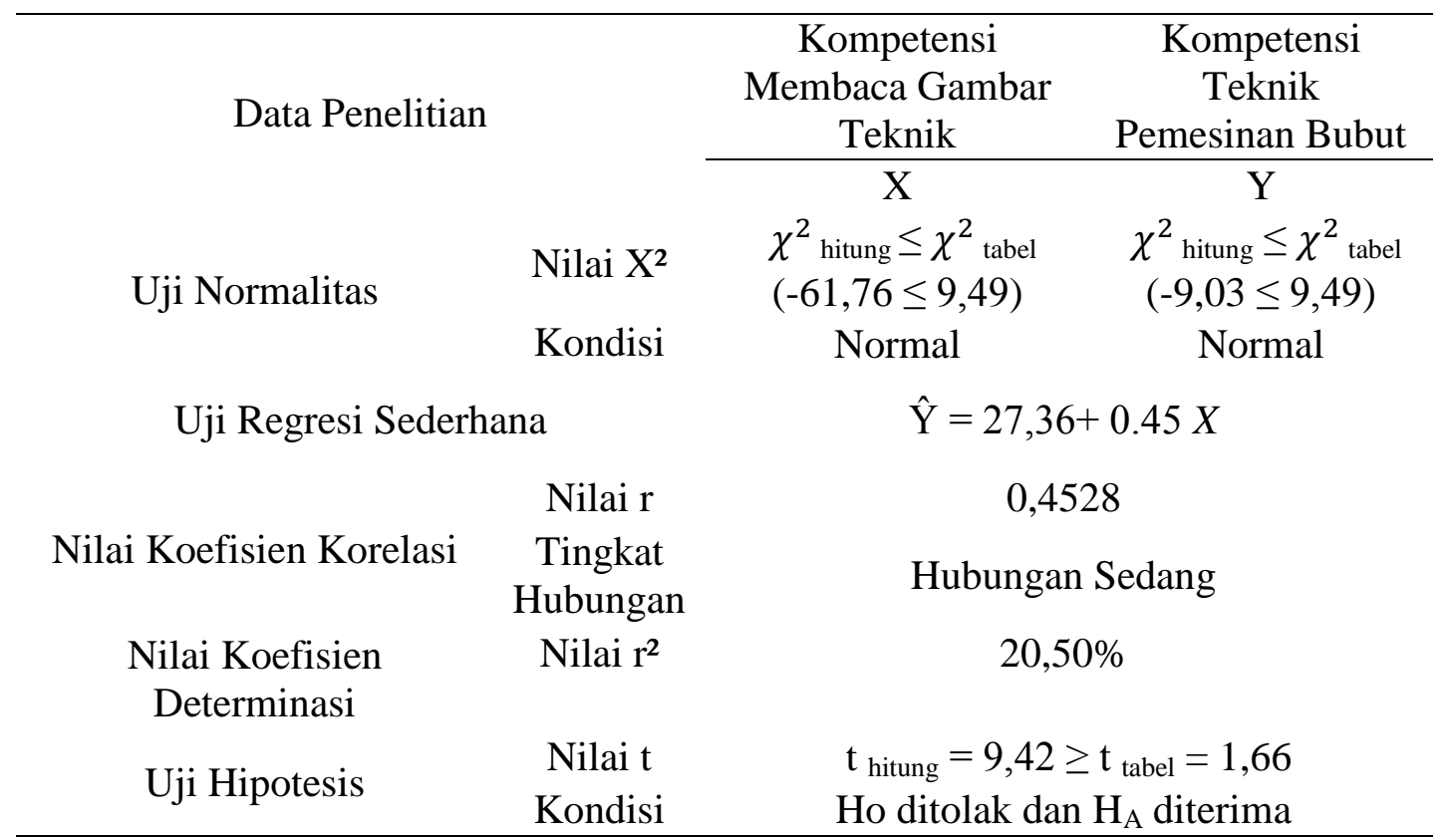

Pengujian hipotesis yang diajukan adalah besarnya pengaruh variabel bebas terhadap variabel terikat, pengujian ini dilakukan dengan menggunakan uji $t$ dengan kriteria pengujian terima $\mathrm{H}_{0}$ bila $\mathrm{t}_{\text {hitung }}<\mathrm{t}_{\text {tabel }}$ pada taraf nyata 5\% dan taraf kepercayaan 95\% dengan $\mathrm{dk}=\mathrm{n}-2$. Hasil perhitungan diperoleh nilai koefisien korelasi $t_{\text {hitung }}=9,42$, sedangkan besarnta $t_{\text {tabel }}$ pada tingkat kepercayaan 95\% dengan derajat kebebasan $\mathrm{dk}=\mathrm{n}-2=89$ didapat $\mathrm{t}_{(0,95)(89)}=1,66$. Dengan demikian berdasarkan kriteria pengujian ternyata $t_{\text {hitung }} \geq t_{\text {tabel }}$ maka hipotesis $H_{A}$ diterima, yaitu kompetensi membaca gambar teknik memberikan kontribusi sedang terhadap kompetensi teknik pemesinan bubut.

\section{PEMBAHASAN}

Setelah diperoleh data mengenai hasil kompetensi gambar teknik dari hasil pemberian soal dan kompetensi teknik pemesinan dari hasil nilai, langkah selanjutnya adalah melakukan analisis terhadap data-data yang telah didapat tersebut. Dalam penelitian ini, analisis data yang dilakukan meliputi uji normalitas, uji regresi sederhana, perhitungan koefisien korelasi, perhitungan koefisien determinasi, dan pengujian hipotesis.

Berdasarkan hasil penelitian menunjukan bahwa 79 peserta didik memiliki penguasaan membaca gambar teknik yang masuk kedalam kategori cukup. Jika dilihat dari segi instrumen 
penelitian, peserta didik menjawab item pertanyaan dengan benar berada di tengah-tengah nilai rata-rata kelas. Hal ini menunjukan bahwa penguasaan membaca gambar teknik pada peserta didik cukup dalam hal membaca gambar susunan, membaca gambar pandangan, membaca ukuran-ukuran pada gambar, mengidentifikasi tanda pengerjaan dan suaian pada gambar.

Berhasil tidaknya pencapaian tujuan pendidikan atau baik tidaknya prestasi peserta didik banyak bergantung kepada bagaimana proses belajar yang dialami oleh peserta didik sebagai anak didik. Sementara proses belajar mengajar sangat dipengaruhi oleh beberapa faktor agar tercapai prestasi belajar yang baik, faktor tersebut diantaranya adalah faktor internal dan faktor eksternal. Faktor internal dan eksternal adalah faktor jasmani serta faktor psikologi (internal) dan lingkungan keluarga serta faktor sekolah (eksternal). Namun faktor yang mempengaruhi keberhasilan belajar terletak pada siswa itu sendiri (Slameto, 2003).

Peningkatan motivasi peserta didik menjadi tugas guru, guru harus mampu memberikan dorongan dan memperbaiki metode pembelajarannya untuk membangkitkan motivasi peserta didik dalam belajar sehingga akan meningkatkan penguasaan peserta didik terhadap materi pelajaran yang diikutinya. Pada gilirannya dengan motivasi yang tinggi akan mampu meningkatkan hasil belajar peserta didik.

Berdasarkan hasil penelitian menunjukan bahwa 81 peserta didik memiliki penguasaan kompetensi dalam kerja bubut sederhana yang termasuk kedalam kategori cukup. Penyebab hasil yang didapat dari penelitian pada Teknik Pemesinan dengan taraf cukup tidak hanya dapat dilihat dari instrument tetapi dapat dilihat pula faktor-faktor yang mempengaruhi proses belajar maupun prestasi belajar peserta didik, yaitu faktor eksterna dan internal.

Terkait dengan faktor internal, peserta didik masih tergolong kurang dalam hal daya tangkap dan daya serap. Hal ini terbukti dengan masih kurangnya peserta didik dalam menguasai pengetahuan sebelumnya dan keterampilan dasar pada mata pelajaran Teknik Pemesinan. Selain itu kebiasaan belajar yang kurang baik juga sikap yang kurang positif terhadap mata pelajaran Teknik Pemesinan. Oleh karena itu, pada saat pembelajaran Teknik Pemesinan, guru hendaknya merubah strategi pembelajaran sedemikian rupa hingga dapat menarik perhatian peserta didik dalam belajar.

Sementara untuk faktor eksternal disebabkan oleh ruang belajar yang tidak nyaman atau tidak tersedianya fasilitas lain seperti cara mengajar guru dan mesin-mesin yang akan 
digunakan banyak yang tidak bisa digunakan. Hasil pengujian statistik didapatkan $\mathrm{t}$ hitung $=$ $9,42 \geq \mathrm{t}_{\text {tabel }}=1,66$ dengan hasil tersebut maka penelitian ini menerima hipotesis alternative $\left(\mathrm{H}_{\mathrm{A}}\right)$ bahwa kompetensi Gambar Teknik memberikan kontribusi signifikan terhadap kompetensi Teknik Pemesinan. Dengan diterimanya $\mathrm{H}_{\mathrm{A}}$ maka hal ini menunjukan bahwa ternyata adanya kontribusi antara Kompetensi Membaca Gambar Teknik Terhadap Kompetensi Teknik Pemesinan Bubut.

Kompetensi membaca gambar teknik berpengaruh terhadap kompetensi teknik pemesinan bubut (Sato, 1999). Hal ini dibuktikan juga dengan perhitungan statistik dimana kompetensi membaca gambar teknik berkontribusi terhadap kompetensi teknik pemesinan bubut. Besarnya kontribusi berdasarkan perhitungan statistik sebesar rs $=0,4528$. Dengan demikian dalam penelitian ini kontribusi kompetensi membaca gambar teknik terhadap kompetensi teknik pemesinan bubut berkontribusi sedang, sedangkan korelasinya sedang. Hal ini berarti nilai penguasaan membaca gambar teknik memiliki tingkat kontribusi terhadap penguasaan praktikum teknik pemesinan sebesar 20,50\%, dengan kata lain semakin baik penguasaan gambar teknik, maka kemungkinan besar akan semakin baik pula dalam praktikum teknik pemesinan yang dicapai peserta didik. Sementara sisanya 79,50\% dipengaruhi oleh faktor lain.

\section{KESIMPULAN}

Kesimpulan penelitian ini yaitu: penguasaan Kompetensi Membaca Gambar Teknik peserta didik kelas XI TPM SMK Negeri 6 Bandung tahun ajaran 2014/2015 berada pada kategori sudah memenuhi standar KKM. Penguasaan Kompetensi Teknik Pemesinan Bubut peserta didik kelas XI TPM SMK Negeri 6 Bandung tahun ajaran 2014/2015 berada pada kategori sudah memenuhi standar KKM. Kompetensi Membaca Gambar Teknik berkontribusi sedang terhadap Kompetensi Teknik Pemesinan. Terdapat kontribusi sedang untuk kompetensi Gambar Teknik tahun ajaran 2014/2015 dengan kompetensi Teknik Pemesinan.

\section{DAFTAR PUSTAKA}

Mulyasa, E. (2003). Kurikulum Berbasis Kompetensi. Bandung: Remaja Rosdakarya.

Slamento. (2003). Belajar dan Faktor-Faktor Yang Mempengaruhinya (Edisi Revisi). Jakarta: Rineka Cipta. 
Suherman, A. \& Hidayat, H. (2008). Modul Perencanaan Pengajaran. Bandung: JPTM FPTK.

SMKN 6. (2009). KTSP Teknik Pemesinan SMK Negeri 6 Bandung. Bandung: SMK Negeri 6 Bandung.

Surakhmad, W. (2000). Pengantar Penelitian Ilmiah Dasar Metode Teknik. Bandung : Tarsito.

Sato, T. G. (1999). Menggambar Mesin. Jakarta : PT. Pradnya Paramita. 